\title{
New insights in the analysis of blunt force trauma in human bones. Preliminary results
}

\author{
Sarah Scheirs ${ }^{1,2}$ • Assumpció Malgosa ${ }^{2}$ - David Sanchez-Molina ${ }^{3}$. \\ Marisa Ortega-Sánchez ${ }^{1,4}$ - Joan Velázquez-Ameijide ${ }^{3}$ - Carlos Arregui-Dalmases ${ }^{3}$. \\ Jordi Medallo-Muñiz ${ }^{1}$ - Ignasi Galtés ${ }^{1,2,5}$
}

Received: 22 January 2016 / Accepted: 2 December 2016

(C) Springer-Verlag Berlin Heidelberg 2016

\begin{abstract}
Determining the time of injury is an important but still a challenging task in forensic anthropology. In literature, many descriptions can be found to make a distinction between perimortem and postmortem fractures. Characteristics that are more related to fractures in fresh conditions, however, are not extensively investigated. This study compared 28 perimortem fractures from autopsies and 21 both fresh and dry experimentally reproduced human bone fractures. Preliminary results showed the following five distinct traits that might be related to perimortem conditions: layered breakage, bone scales, crushed margins, wave lines and flakes with matching flake defect. These distinct traits might not only be good estimators of perimortem trauma but also may be an indicator of trauma in intra vitam conditions, especially related with muscular reaction to injury. Furthermore, layered
\end{abstract}

Ignasi Galtés

ignasigaltes@gmail.com

1 Forensic Anthropology Unit, Catalonian Institute of Legal Medicine and Forensic Science (IMLCFC), Ciutat de la Justícia, Gran Via de les Corts Catalanes, 111 Edifici G, 08075 Barcelona, Spain

2 Department of Animal Biology, Vegetal Biology and Ecology, Facultat de Ciències, Universitat Autònoma de Barcelona, Bellaterra, 08193 Barcelona, Spain

3 Universitat Politècnica de Catalunya (UPC) - EEBE, Eduard Maristany 10-14, 08019 Barcelona, Spain

4 Unitat d'Anatomia i d'Embriologia, Departament de Ciències Morfològiques, Facultat de Medicina, Universitat Autònoma de Barcelona, Bellaterra, 08193 Barcelona, Spain

5 Legal Medicine Unit, Department of Psychiatry and Legal Medicine, Facultat de Medicina, Universitat Autònoma de Barcelona, Bellaterra, 08193 Barcelona, Spain breakage seems to be a good trait to infer the biomechanics of trauma.

Keywords Forensic anthropology · Bone trauma . Time of injury $\cdot$ Perimortem trauma

\section{Introduction}

The interpretation of bone trauma is an important task for forensic anthropologists. The mechanical properties of bone allow anthropologists to attempt to reconstruct the biomechanics of trauma and to derive knowledge about possible circumstances related to the manner of injury [1]. This allows professional forensic anthropologists to complement the work of forensic pathologists in the assessment of bone injuries in fresh cadavers $[2,3]$. One of the main and most important challenges in trauma analysis however is the assessment of the time of injury [4].

To assess the time an injury occurred, a distinction is made between antemortem, perimortem and postmortem trauma [5]. Antemortem trauma is defined as trauma that occurs prior to death and where signs of bone remodelling can be observed on the edges of the fractures. These antemortem injuries are of great value for forensic anthropologists as they can contribute to the identification of skeletal remains [6, 7]. On both perimortem and postmortem trauma, there are no signs of healing. Although there are some known morphological or possible colour differences, the differentiation between perimortem trauma and postmortem taphonomic factors such as geological, biological or (un)intentional human alterations remains difficult $[4,8-11]$.

According to Symes et al. (2012), anthropologists use the term perimortem when they imply that trauma was inflicted when the bone still has its organic components causing it to 
behave as fresh bone [12]. Therefore, it is difficult to distinguish an injury that is associated with the death of an individual from an event that occurs in a period of time close after death, when bone is still fresh [7, 13]. Due to varying circumstances in decomposition rates, the length of this period, the perimortem interval, can vary significantly. For this reason, the perimortem stage has an unpredictable time span and may occupy a long period of time. Nawrocki (2009) argues that the perimortem interval lasts until skeletal remains exhibit postmortem, dry bone, characteristics [10, 14, 15]. From a medicolegal point of view, the perimortem stage is important, since any injury directly associated with the manner of death is considered a perimortem injury $[4,5]$.

In literature, there are already many characteristics known to make the distinction between perimortem and postmortem fractures like colour, smooth and rough edges [8, 16, 17]. In reality, however, this distinction is still a challenge in forensic cases, especially when the bones are still fresh. From our knowledge, there are no studies that shorten the perimortem interval by defining distinct intra vitam traits. The present study focused on perimortem blunt force trauma in human long bones. Blunt force trauma is a result of a slow load applied to bone. These kinds of injuries define all injuries from homicidal assault, blows by an object to the head or torso, traffic accidents and falls from heights $[8,18]$.

The main aim of this study is to obtain bone patterns that might allow us to optimise the distinction between perimortem and postmortem fractures. This will be done by means of comparing fractured specimens from autopsies with experimental reproduced fractures. We hypothesise that there may be specific intra vitam traits. In order to test our hypothesis, we will investigate macroscopic characteristics that define a distinct perimortem pattern by searching for evidence that might suggest the presence of musculoskeletal activity and surrounding flesh. In case we would find such evidence, we will try to reproduce them in both dry and fresh bones.

\section{Materials and methods}

This study used both perimortem fractured and healthy unfractured bone samples. In total, 28 fractured specimens from 16 cases were used in this study (Table 1). These specimens came from forensic autopsies at the Institute for Legal Medicine and Forensic Science of Catalonia (IMLCFC), which were removed for complementary medicolegal investigation. The Medical Anatomy Department of the Autonomous University of Barcelona (UAB) provided 21 healthy, unfractured, fresh and dry bones from people that donated their bodies to science (Table 2). This study was approved by the Ethics Commission of Human and Animal Experimentation (CEEAH) work of the UAB, in order to comply with the ethical requirements.
Table 1 Descriptive table of perimortem bone fractures from autopsies (IMLCFC)

\begin{tabular}{|c|c|c|c|c|}
\hline Case no. & Type of bone & Sex & Age & Trauma circumstances \\
\hline \#001 & $\begin{array}{l}\text { Femur }(\times 2) \\
\text { Tibia }(\times 2) \\
\text { Fibula }(\times 2)\end{array}$ & Male & 22 & Traffic accident \\
\hline$\# 002$ & $\begin{array}{l}\text { Humerus } \\
\text { Ulna } \\
\text { Femur }\end{array}$ & Male & 20 & Traffic accident \\
\hline \#003 & $\begin{array}{l}\text { Humerus } \\
\text { Ulna } \\
\text { Radius }\end{array}$ & Male & 56 & Traffic accident \\
\hline$\# 004$ & Femur & Male & 50 & Traffic accident \\
\hline \#005 & Humerus & Female & 41 & Fall \\
\hline \#006 & Humerus & Female & 30 & Fall \\
\hline$\# 007$ & $\begin{array}{l}\text { Tibia } \\
\text { Fibula }\end{array}$ & Male & 73 & Traffic accident \\
\hline \#008 & Humerus & Male & 83 & Fall \\
\hline \#009 & Femur & Male & 77 & Fall \\
\hline \#010 & Humerus & Male & 39 & Fall \\
\hline \#011 & Femur & Male & 34 & Fall \\
\hline \#012 & Femur $(\times 2)$ & Male & 25 & Traffic accident \\
\hline \#013 & Femur & Male & 49 & Fall \\
\hline \#014 & Femur & Female & 63 & Fall \\
\hline \#015 & Femur & Male & 85 & Fall \\
\hline \#016 & $\begin{array}{l}\text { Humerus } \\
\text { Ulna }\end{array}$ & Male & 39 & Fall \\
\hline
\end{tabular}

Table 2 Fresh and dry bone samples from donors (UAB)

\begin{tabular}{llll}
\hline No. & Type of bone & Sex & Age \\
\hline Exp\#001 & Fresh humerus & Female & 94 \\
Exp\#002 & Fresh humerus & Male & 74 \\
Exp\#003 & Fresh humerus & Male & 67 \\
& Fresh ulna & & \\
Exp\#004 & Fresh radius & & \\
Exp\#005 & Fresh humerus & Female & 86 \\
Exp\#006 & Fresh femur & Female & 88 \\
Exp\#007 & Fresh femur & Male & 68 \\
Exp\#008 & Fresh femur & Male & 46 \\
Exp\#009 & Fresh humerus & Female & 94 \\
Exp\#010 & Fresh humerus & Female & 81 \\
Exp\#011 & Dry humerus & Male & 62 \\
Exp\#012 & Dry fibula & Male & 70 \\
Exp\#013 & Dry humerus & Female & 86 \\
Exp\#014 & Dry humerus & Male & 85 \\
Exp\#015 & Dry tibia & Female & 72 \\
Exp\#016 & Dry femur & Female & 64 \\
Exp\#017 & Dry fibula & Male & 83 \\
Exp\#018 & Dry radius & Male & 78 \\
Exp\#019 & Dry ulna & Male & 68 \\
\hline
\end{tabular}




\section{Fracture reproduction}

The fresh bones from the UAB were provided completely defleshed with only the periosteum remaining attached. These fresh and dry human bones (Table 2) were used to reproduce fractures in order to compare them to the samples received from autopsies (Table 1). The samples from autopsies were defined as intra vitam fractures; they occurred close to the time of death without signs of healing. Fracturing a long bone will result in different types of fractures depending on how the force is applied to the bone. They can result in transverse fractures, oblique fractures, spiral fractures and butterfly fractures (like our samples in Table 3) [19, 20].

In this study, a three-point bending (referred to as 3-PB in Table 4) was conducted to experimentally reproduce postmortem fractures. This was done with the use of a servo-hydraulic testing machine from research group GRABI (EM2/20 MicroTest, with an U10M/25-kN loading cell) and was controlled through the SCM3000 program (Fig. 1). To break the bones, cellulose blocks were used on the two supports and the loading cell as an attempt to simulate soft tissue and to prevent direct contact on the bone. The bending tests were performed on six fresh and four dry human bones at a strain rate of $160 \mathrm{~mm} / \mathrm{min}$ (Table 3). A three-point bending results in a tension side opposite to a compression side and is chosen since it is a common type of fracture in long bones [21]; furthermore, it is easy to control. In this type of bending, the tension side will fail first under the applied force and will continue in two directions until it reaches the compression side; this will usually result in a butterfly fracture [18].

The relation between force and stress during bending can be written as the following Eq. [22]:

Stress $=\frac{\text { Axial force }}{\text { Area }}-\frac{\text { Bending moment }}{\text { Second area moment }} \times$ Distance

where the 'axial force' is zero when no compression is applied to the bone. When compression was applied with the tensors,

Table 3 Overview of all the available samples and corresponding traits that were present (+) and/or absent (-)

Case no. Type of bone Bone Sample Type of fracture
Perimortem pattern

Layered Wave lines Bone scales Flakesflake Crushed breakage

defect margins

\begin{tabular}{|c|c|c|c|c|c|c|c|c|c|}
\hline \multirow{28}{*}{$\begin{array}{l}\text { Fractured } \\
\text { specimens } \\
\text { (IMLCFC) }\end{array}$} & \multirow[t]{6}{*}{$\# 001$} & Femur (R) & 1 & Transverse & + & - & - & + & + \\
\hline & & Femur (L) & 2 & Transverse & + & - & + & + & - \\
\hline & & Tibia (R) & 3 & Comminuted at epiphysis & + & - & + & + & - \\
\hline & & Tibia (L) & 4 & Butterfly & + & - & - & + & - \\
\hline & & Fibula (R) & 5 & Epiphysial & - & - & - & - & - \\
\hline & & Fibula (L) & 6 & Transverse & + & - & - & - & + \\
\hline & \multirow[t]{3}{*}{$\# 002$} & Humerus & 7 & Oblique & + & - & - & - & - \\
\hline & & Ulna & 8 & Transverse & + & - & - & - & - \\
\hline & & Femur & 9 & Comminuted spiral & + & + & - & - & - \\
\hline & \multirow[t]{3}{*}{ \#003 } & Humerus & 10 & Comminuted at epiphysis & - & - & - & - & - \\
\hline & & Ulna & 11 & Transverse & + & - & - & + & - \\
\hline & & Radius & 12 & Epiphysial & - & - & - & - & - \\
\hline & \#004 & Femur & 13 & Comminuted & + & - & - & + & - \\
\hline & \#005 & Humerus & 14 & Comminuted & + & - & - & + & - \\
\hline & \#006 & Humerus & 15 & Spiral & - & + & - & - & - \\
\hline & \multirow[t]{2}{*}{ \#007 } & Tibia & 16 & Comminuted & + & - & - & + & - \\
\hline & & Fibula & 17 & Comminuted transversal & + & - & - & - & - \\
\hline & \#008 & Humerus & 18 & Comminuted spiral & - & + & - & - & - \\
\hline & \#009 & Femur & 19 & Comminuted at epiphysis & + & - & - & + & - \\
\hline & \#010 & Humerus & 20 & Comminuted & + & - & + & - & - \\
\hline & \#011 & Femur & 21 & Comminuted & + & - & + & - & + \\
\hline & \multirow[t]{2}{*}{ \#012 } & Femur (R) & 22 & Transverse & + & + & + & - & - \\
\hline & & Femur (L) & 23 & Oblique & + & - & - & + & + \\
\hline & \#013 & Femur & 24 & Comminuted & + & + & + & - & - \\
\hline & \#014 & Femur & 25 & Comminuted transversal & + & + & - & - & - \\
\hline & \#015 & Femur & 26 & Butterfly & + & + & + & + & - \\
\hline & \multirow[t]{2}{*}{ \#016 } & Humerus & 27 & Transverse & + & - & + & + & - \\
\hline & & Ulna & 28 & Transverse & + & - & - & + & - \\
\hline
\end{tabular}


the axial force would be larger than zero. According to Rouvière and Delmas, the biceps creates a compression of $4.8 \mathrm{~kg}$ on the bone and the triceps $8.5 \mathrm{~kg}$ [23]. We estimated that the applied compression was $7 \mathrm{~kg}(70 \pm 5 \mathrm{~N})$, which is in consonance with the range mentioned by Rouvière and Delmas (1988). 'Area' is the total area of the central cross section of the bone. 'Bending moment' is determined by the total applied force and the distance between the two supports. During the experiments, the total force that was applied fluctuated between 1728 and $3489 \mathrm{~N}$. 'Second area moment' is a measure of efficiency of a cross-sectional shape to resist bending when a force is applied. The final variable is the 'distance' from the centre of gravity of the central cross section of the bone to the point where the stress is measured [24].

In order to simulate more real conditions, two specimens were fractured under axial compression since it is well known that when a bone fractures, muscular contraction plays a role [25-27]. We hypothesised that some of the traits might be related to this mechanical loading. The axial compression was created with the use of metallic tensors attached around the proximal and distal bone ends. We assumed that when the fracture starts, the tensors would cause a simulation of muscle contraction.

\section{Bone preparation}

In order to analyse the fractures, the fractured bones from the reproduction experiments and autopsies were defleshed using the method currently used at IMLCFC. Fresh bone samples were placed in a water with detergent solution (one cup of commercial degreasing detergent in $5 \mathrm{~L}$ of water) that was heated up to $100^{\circ} \mathrm{C}$. After it reached $100{ }^{\circ} \mathrm{C}$, the temperature was lowered to $80-90^{\circ} \mathrm{C}$ and the bones were boiled for $2-5 \mathrm{~h}$, depending on the amount of flesh that had to be removed. After cooking, the remaining flesh was physically removed and the bones were placed overnight in a 50\% acetone-water solution to degrease the bones. Afterwards, they were cleaned with water and left to dry. If the bones were very greasy, they were boiled again in a $2.5 \%$ ammonia solution until all the grease was removed.

\section{Results}

During the macroscopic examination of the non-experimental fractured bones, four distinct characteristics could be observed with the naked eye being layered breakage in the compression side, bone scales in the compression side, flakes with flake defect and crushed margins. One-trait, wave lines were easier, but not exclusively, visualised when using some magnification $(\times 10-\times 40)$. These traits are summarised in Table 3 and defined a perimortem pattern. Later, these patterns were compared to the experimentally broken bones (Table 4).
Layered breakage (Fig. 2) could be observed in $82 \%$ of the fractured samples from autopsies and in all the experimental postmortem fractures in fresh bone. This trait was always present in the compression side when a fracture takes place in the diaphysis of a long bone. Layered breakage is very distinctive since it is a pattern that occurs in the cortical bone rather than the surface or edge of the bone. The remaining $18 \%$ of samples, where layered breakage was not observed, were spiral fractures and fractures at the epiphyses. Furthermore, we were not able to experimentally reproduce this trait in dry bones.

Wave lines appeared on the smooth edges of fractures. It is a smooth undulation that has a gentle slope and a rapid drop, resembling a 'wave' (Fig. 3). This trait could mostly be observed in butterfly fractures, spiral fractures and comminuted fractures with large pieces where the edges were smooth and long.

Bone scales appeared on the compression side and resemble 'fish scales' (Fig. 4). These bone scales are a form of plastic deformation that is tangible. They occur close to the margin of the fracture, but there is still some space left between the margin and the first scales occurring. They were small and very superficial, but there were also cases where they were thicker.

A flake is a result of a broken bone scale or a superficial loss of bone (Fig. 5). When one of the scales breaks off, it is referred to as a flake (Fig. 5c). Flakes are rarely recovered since they tend to get lost in the surrounding flesh in fresh fractures. The imprint that is left on the bone is defined as a flake defect. This may resemble a bevel; however, a bevel goes through the entire cortical bone [8]. A flake defect is only superficial or until the middle of the cortical.

Crushed margins are similar to bone scales, but occur on the margin of the fracture, making this trait very vulnerable for destruction (Fig. 6). Moreover, they were only observed on the compression side.

As seen in Table 4, none of these distinct features could be experimentally reproduced in dry bones, in contrast to the fresh bones where some of them were reproduced. Dry bone fractures had a very different structure than the fresh ones (Fig. 7). In all the fresh bones, without compression, layered breakage could be reproduced. In the fresh bones with compression, observations were made of layered breakage, bone scales and flakes with flake defects. Additionally, only in the fresh bones with compression, plastic deformation could be observed.

\section{Discussion}

When bone is subjected to blunt trauma, it will undergo two mechanisms before a fracture occurs. In the first phase, the bone will undergo elastic deformation. This 
Table 4 Overview of the experimental samples and corresponding traits that were present $(+)$ and/or absent $(-)$

\begin{tabular}{|c|c|c|c|c|c|c|c|c|c|c|}
\hline & \multirow[t]{2}{*}{ Case no. } & \multirow{2}{*}{$\begin{array}{l}\text { Type of } \\
\text { bone }\end{array}$} & \multirow{2}{*}{$\begin{array}{l}\text { Bone } \\
\text { sample }\end{array}$} & \multirow[t]{2}{*}{ Type of loading } & \multirow[t]{2}{*}{ Type of fracture } & \multicolumn{5}{|c|}{ Perimortem pattern } \\
\hline & & & & & & $\begin{array}{l}\text { Layered } \\
\text { breakage }\end{array}$ & $\begin{array}{l}\text { Wave } \\
\text { lines }\end{array}$ & $\begin{array}{l}\text { Bone } \\
\text { scales }\end{array}$ & $\begin{array}{l}\text { Flakes/flake } \\
\text { defect }\end{array}$ & $\begin{array}{l}\text { Crushed } \\
\text { margins }\end{array}$ \\
\hline \multirow{11}{*}{$\begin{array}{l}\text { Fresh sp. } \\
\text { (UAB) }\end{array}$} & Exp\#001 & Humerus & E1 & 3-PB & Transverse & + & - & - & - & - \\
\hline & Exp\#002 & Humerus & $\mathrm{E} 2$ & $3-\mathrm{PB}$ & Transverse & + & - & - & - & - \\
\hline & \multirow[t]{3}{*}{ Exp\#003 } & Humerus & E3 & \multirow{2}{*}{$\begin{array}{l}\text { 3-PB + axial } \\
\text { compression }\end{array}$} & Very small butterfly & + & - & + & + & - \\
\hline & & Ulna & $\mathrm{E} 4$ & & Very small butterfly & + & - & - & - & - \\
\hline & & Radius & E5 & $\begin{array}{l}3-\mathrm{PB} \\
3-\mathrm{PB}\end{array}$ & Oblique & + & - & - & - & - \\
\hline & Exp\#004 & Humerus & E6 & $\begin{array}{l}\text { 3-PB + axial } \\
\text { compression }\end{array}$ & Transverse & + & - & + & + & - \\
\hline & Exp\#005 & Femur & E7 & $3-\mathrm{PB}$ & Transverse & + & - & - & - & - \\
\hline & Exp\#006 & Femur & E8 & $\begin{array}{l}\text { 3-PB + axial } \\
\text { compression }\end{array}$ & Oblique & + & + & + & + & - \\
\hline & Exp\#007 & Femur & E9 & $\begin{array}{l}\text { 3-PB + axial } \\
\text { compression }\end{array}$ & Transverse & + & + & + & - & - \\
\hline & Exp\#008 & Humerus & E10 & $3-\mathrm{PB}$ & Transverse & + & - & - & - & - \\
\hline & Exp\#009 & Humerus & E11 & $3-\mathrm{PB}$ & Transverse & + & - & - & - & - \\
\hline \multirow{10}{*}{$\begin{array}{l}\text { Dry sp. } \\
\text { (UAB) }\end{array}$} & Exp\#010 & Humerus & E12 & 3-PB & Fake butterfly & - & - & - & - & - \\
\hline & Exp\#011 & Fibula & E13 & 3-PB & Comminuted & - & - & - & - & - \\
\hline & Exp\#012 & Humerus & E14 & 3-PB & Oblique & - & - & - & - & - \\
\hline & Exp\#013 & Humerus & E15 & $3-\mathrm{PB}$ & Comminuted & - & - & - & - & - \\
\hline & Exp\#014 & Tibia & E16 & 3-PB & Transverse & - & - & - & - & - \\
\hline & Exp\#015 & Femur & E17 & 3-PB & Transverse & - & - & - & - & - \\
\hline & Exp\#016 & Fibula & E18 & $3-\mathrm{PB}$ & Transverse & - & - & - & - & - \\
\hline & Exp\#017 & Radius & E19 & 3-PB & Comminuted & - & - & - & - & - \\
\hline & Exp\#018 & Ulna & E20 & $3-\mathrm{PB}$ & Comminuted & - & - & - & - & - \\
\hline & Exp\#019 & Ulna & E21 & 3-PB & Fake butterfly & - & - & - & - & - \\
\hline
\end{tabular}

means that the bone can return to its original dimensions. In the second phase, it will endure plastic deformation, which will deform the bone permanently. The plastic phase will continue until breaking occurs [9, 28]. Fresh bone is moist and contains water and organic components as lipids and collagen, which make the bone stiff and elastic. Dry bone lacks these organic components, which make the bone stiff but brittle [29]. The loss of viscoelasticity in dry bone makes the bone unable to withstand as much strain or elastic deformation as wet bone and is more sensitive to degradation. This will cause dry bone to fracture immediately after the strength threshold is reached, whereas wet bone will first go through a plastic phase where the bone is deformed before fracturing [9,
18]. Therefore, the fracture patterns in dry and fresh fractures will be different [30].

Macroscopic patterns that are used to differentiate between perimortem and postmortem fractures are a consequence of those bone biomechanics and composition characteristics. Macroscopic descriptions are preferred in fracture assessment since this is the fastest and easiest way in the field. For this reason, our study was focused on the macroscopic appearance of fractures. Colour is a reliable and known trait as any fracture after decomposition will give a different colour, which will make it possible to differentiate the old (perimortem) from the newly (postmortem) exposed bone surfaces. However, colours can change again after alteration due to acquired patina through the years. This means that, if there is no colour 


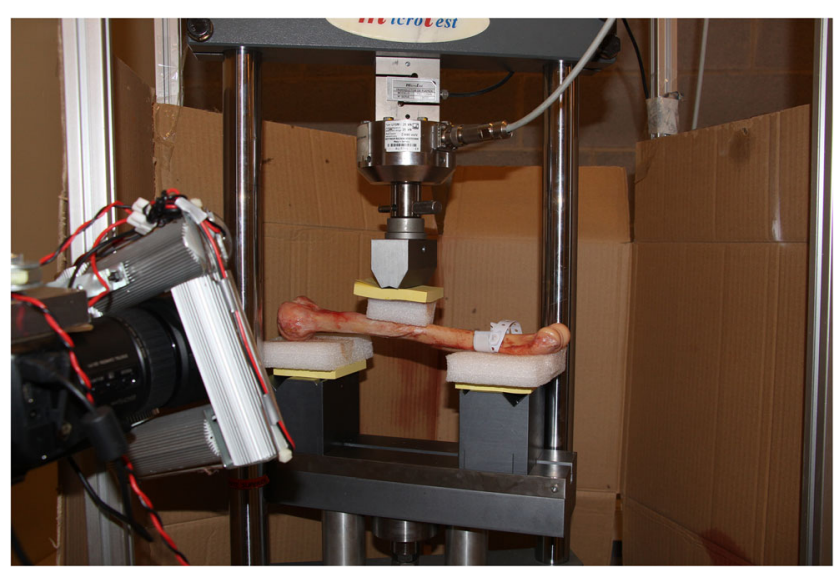

Fig. 1 Servo-hydraulic testing machine EM2/20 MicroTest, with the U10M/25-kN loading cell and two supports to create a three-point bending, from UPC

difference, it does not necessarily mean that the fracture can only be perimortem $[9,18]$. The general appearance of bone is
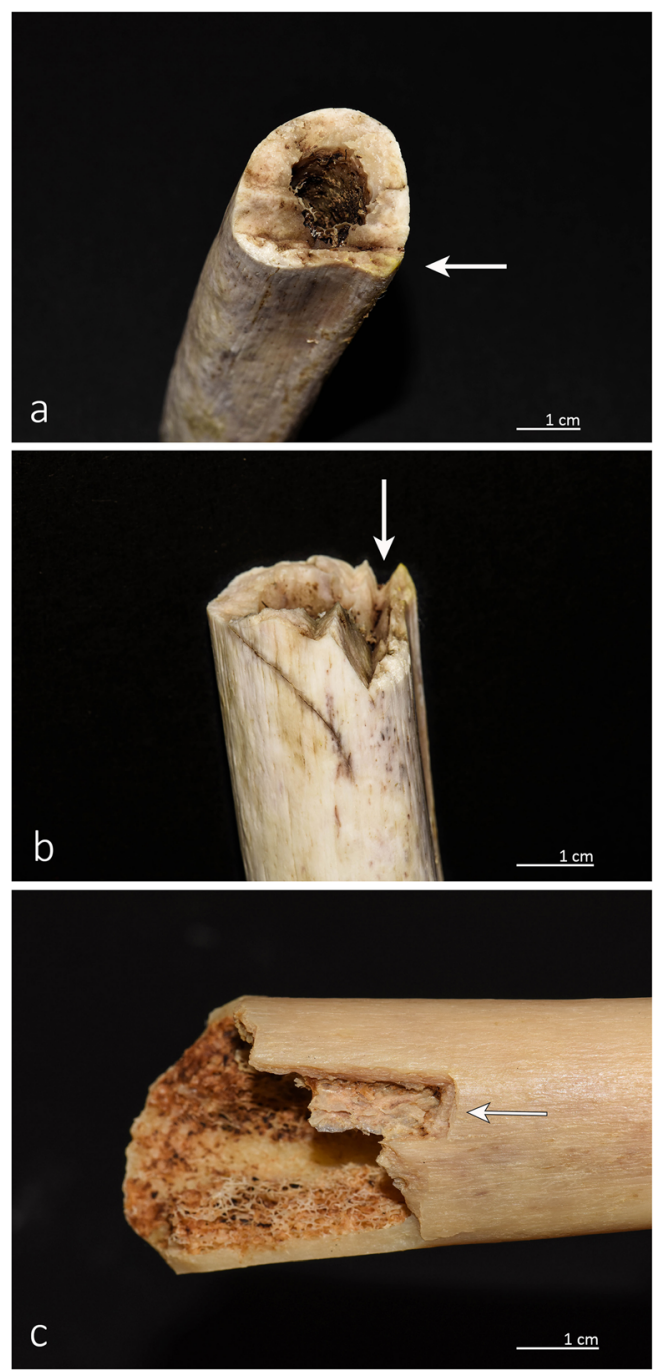

Fig. 2 The white arrows indicate the layered breakage in the cortical bone, opposite to a straight tension side (a, b sample 2 and $\mathbf{c}$ sample 19)
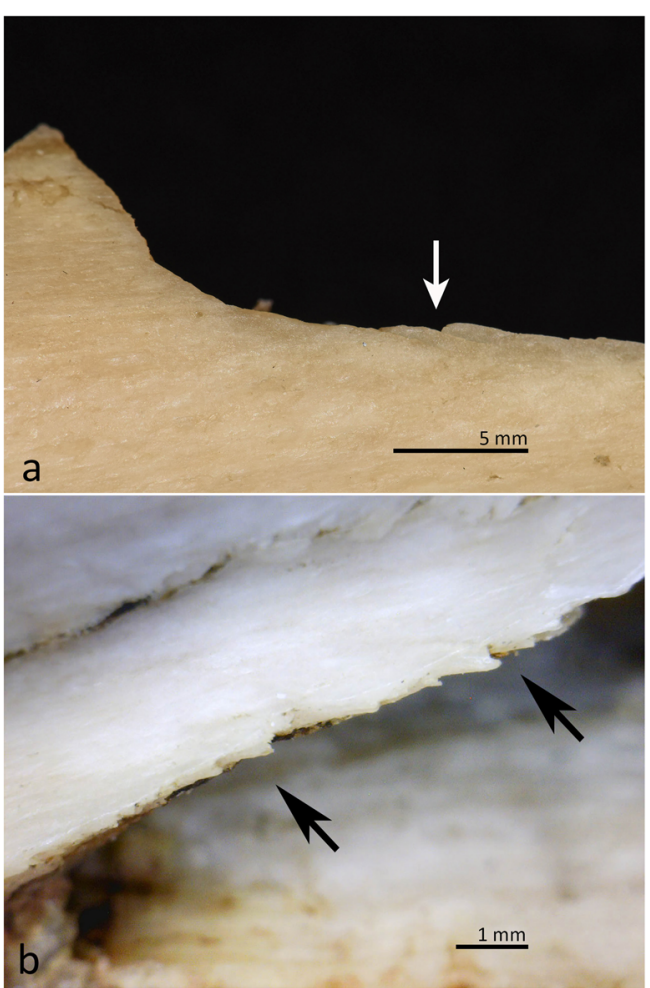

Fig. 3 Wave lines on the smooth edges of a fracture (a sample 26 and b sample 22)

also an important trait. Dry bone is much more brittle, causing fracture lines to run along or perpendicular to the grain of the bone causing jagged edges $[8,9,16]$. Notwithstanding, the differentiation between very fresh and very dry fractures is easy; in the forensic field, most of the recovered bones are in an intermediate stage between very fresh and extremely dry.

Bones that are in an intermediate stage of drying do not meet these extreme conditions. Therefore, it would be more valuable to obtain additional knowledge about characteristics that are linked more to fresh conditions. With an experimental approach, we were able to reproduce fracture patterns similar to those found in traumatic cases and compare them to find

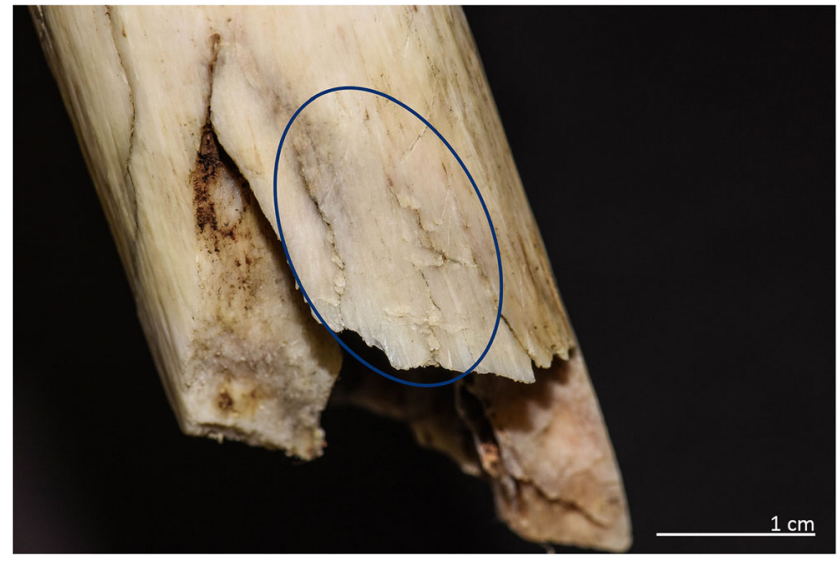

Fig. 4 Bone scales in a compressed area of a fracture (sample 22) 

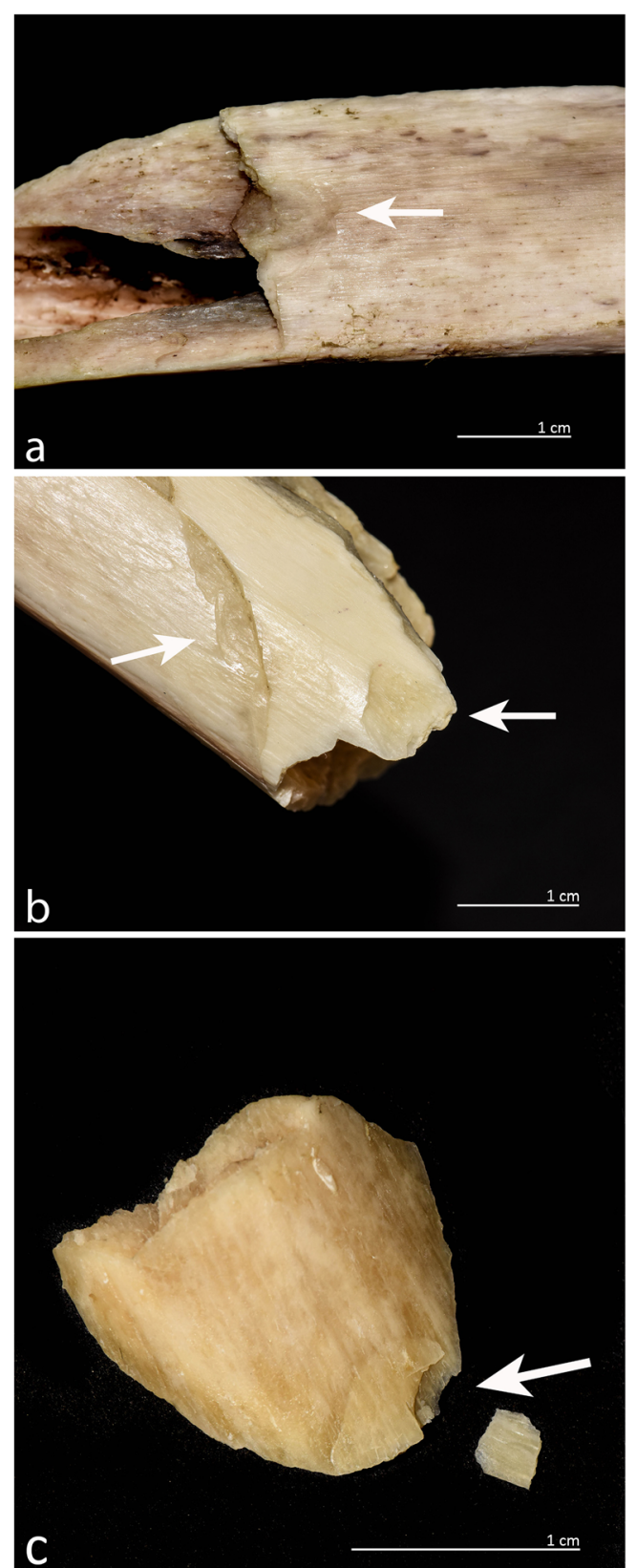

Fig. 5 a, b Several flake defects on the bone surface (samples 2 and 14, respectively) and $\mathbf{c}$ a piece of bone with a flake defect and matching flake from an experimentally reproduced fracture (sample E3)

specific patterns that may be used in forensic examinations. This study reports the following five distinct characteristics that can be valuable traits to utilise in the distinction between perimortem and postmortem fractures: layered breakage, bone scales, crushed margins, flakes with flake defect and wave lines. These characteristics constitute a specific, unreported perimortem pattern; however, not all characteristics must be involved in all perimortem lesions.

Our results showed that layered breakage was the most common perimortem trait, which occurred in $82 \%$ of the samples. This morphological feature occurred in almost all our

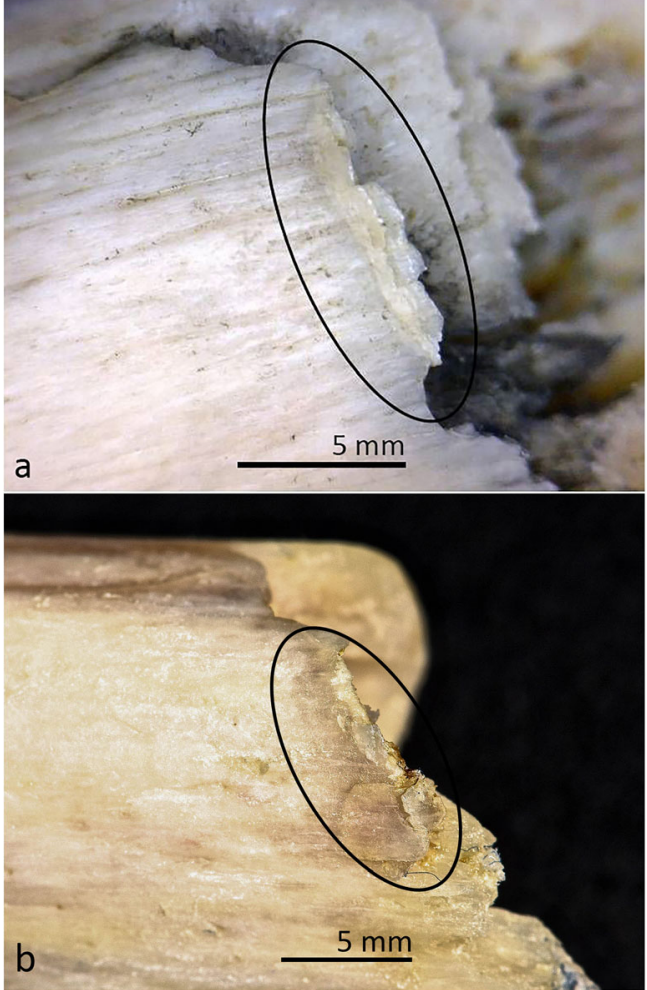

Fig. 6 Crushed margins on the edge of a fracture in the compression side (a sample 23 and b sample 21)

fresh perimortem and postmortem fractures, and it can be considered as a specific trait of the compression side. Only in spiral fractures and fractures at the epiphyses, layered breakage could not be observed. The edges of spiral fractures are very smooth, which was the reason that this feature was not observed in this type of fracture. Nevertheless, the presence of a spiral fracture is already a sign that the fracture is most likely a perimortem fracture since this type of fracture is not likely to appear in dry bone fractures [16]. During bending, the process of fracturing will start at the tension side and

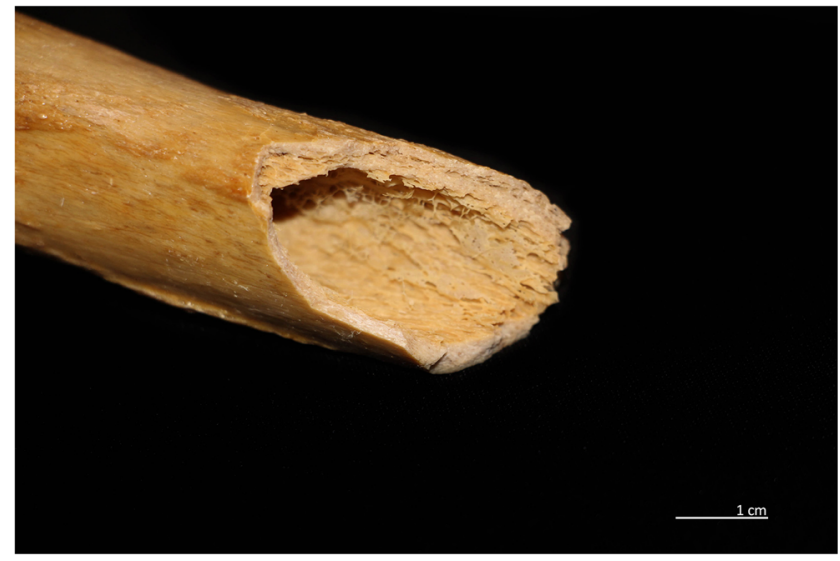

Fig. 7 Fractured dry bone with clear irregular and brittle edge 
will continue towards the compression side. In literature, it is mentioned that the tension side is regular and smooth and the compression edge is irregular [18]. However, we observed a characteristic layered pattern in the cortical area that is unreported in literature. As this trait always appeared in the compression side, it may be possible to reconstruct the biomechanical properties more precisely and deduce the direction of impact. Since layered breakage only could be reproduced in fresh postmortem fractures, it may be an important trait for fractures in fresh bones and not only limited to intra vitam circumstances.

The next common trait was the presence of flake defects that could be observed in $46 \%$ of the samples. Our findings on flakes are congruent with the findings previously reported by Moraitis et al. [31, 32]. They found signs of flaking on a mandible and a long bone and suggested this as a perimortem trait. In this study, we were able to reproduce flake defects and the other traits under conditions that even might suggest that these traits might be related to intra vitam circumstances. The other traits, bone scales, wave lines and crushed margins, were less common and were only observed in 29,25 and $14 \%$ of the samples, respectively. Crushed margins need a very specific mechanism; this is probably the reason why they occurred infrequently. Bone scales, wave lines, flakes and crushed margins were not observed in dry bone and fresh experimental bone fractures without compression. However, we were able to reproduce bone scales, wave lines and flake (defects) when applying axial compression that seems to be necessary in order for them to be present. We therefore suggest that these distinct traits may be related to the unique micro-architecture of the bone, but more importantly, they may be relying on the presence of muscles and flesh.

One of the challenges in forensic anthropology is to find traits that are clearly related to intra vitam circumstances in order to shorten the time gap between very fresh and very dry fractures. In literature, there is only one trait that suggests an intra vitam fracture. This is when a fractured long bone shows evidence of an axial shortened displacement [25]. We hypothesise that bone scales, flakes with flake defects, crushed margins and wave lines are related to musculoskeletal activity and the presence of surrounding flesh. One of the limitations of this study was the limited sample size. Testing this hypothesis deserves further research, whereby a larger sample size should be obtained. Improving the experimental part could get further knowledge about the occurrence of the traits. Further limitations of this research are the average age of the autopsy samples, being 42 years old, versus the experimental bone samples with an average age of 75 years. However, these limitations might not all be solved as these type of studies depend on the availability of human samples.

In summary, during this early stage study, preliminary results were obtained about a new pattern with five distinct macroscopic characteristics that may be specific for fractures in a perimortem stage. Layered breakage was the most frequent trait found. It was a specific trait that occurred in fractures when the bones were still wet. Furthermore, it was a great indicator of the direction of impact as it could always be observed in the compression side. Additionally, initial results were obtained to relate bone scales, flakes, crushed margins and wave lines to intra vitam circumstances, when muscles and flesh are involved. Future research will potentially improve these criteria. The fact that we possibly could shorten the time gap of time of injury by assessing morphological traits in a fracture that are specific for intra vitam circumstances will allows us to interpret blunt force trauma more accurately in the future.

Acknowledgements Special thanks go to the technicians and personnel staff of the Institut de Medicina Legal i Ciències Forenses de Catalunya (IMLCFC). The authors are grateful to Hannah McGlynn for the English language revision of the manuscript.

\section{References}

1. Sauer NJ, Simson LR (1984) Clarifying the role of forensic anthropologists in death investigations. J Forensic Sci 29:1081-1086

2. Galtés I (2013) Estudio médico forense del cadáver en mal estado. In: Libro X Curso Patología Forense. Sociedad Española de Patología Forense, Logroño, pp. 113-141

3. Tersigni-Tarrant MA, Shirley NR (2013) Forensic anthropology today. In: Tersigni-Tarrant MA, Shirley NR (eds) Forensic Anthropology: An Introduction. CRC Press, Florida

4. Reichs KJ (1998) Forensic osteology: advances in the identification of human remains, 2nd Edition. Charles C Thomas, Springfield

5. Sauer NJ (1998) The timing of injuries and manner of death: distinguishing among antemortem, perimortem, and postmortem trauma. In: Reichs KJ (ed) Forensic osteology: advances in the identification of human remains. Charles C. Thomas, Springfield, pp. 321-332

6. Galloway A, Zephro L, Wedel VL (2014) Diagnostic criteria for the determination of timing and fracture mechanism. In: Wedel VL, Galloway A (eds) Broken bones. Charles C Thomas, Springfield, pp. $47-58$

7. Dirkmaat DC (2012) A companion to forensic anthropology. Wiley-Blackwell, Oxford

8. Christensen AM, Passalacqua N V, Bartelink EJ (2014) Forensic anthropology: current methods and practice. Academic Press, Oxford

9. Symes SA, L'Abbé EN, Stull KE et al (2014) Chapter 13: taphonomy and the timing of bone fractures in trauma analysis. In: Pokines JT, Symes SA (eds) Manual of forensic taphonomy. CRC Press, Florida, pp. 341-365

10. Nawrocki S (2009) Forensic taphonomy. In: Blau S, Ubelaker DH (eds) Handbook of forensic anthropology and archaeology. Left Coast Press, Walnut Creek, pp. 284-295

11. Cappella A, Amadasi A, Castoldi E et al (2014) The difficult task of assessing perimortem and postmortem fractures on the skeleton: a blind text on 210 fractures of known origin. J Forensic Sci 59:15981601

12. Symes SA, L'Abbé EN, Chapman EN et al (2012) Chapter 17: interpreting traumatic injury to bone in medicolegal investigations. In: Dirkmaat DC (ed) A companion to forensic anthropology. Wiley-Blackwell, Oxford, pp. 340-388 
13. Wedel VL, Galloway A (2014) Broken bones. Charles C. Thomas, Springfield

14. Symes SA, Rainwater MS, Chapman EN et al (2008) Patterned thermal destruction of human remains in a forensic setting. In: Schmidt CW, Symes SA (eds) Analysis of burned remains. Academic Press, Oxford, pp. 15-54

15. Ubelaker DH, Adams BJ (1995) Differentiation of perimortem and postmortem trauma using taphonomic indicators. J Forensic Sci 40: 509-512

16. Wieberg DAM, Wescott DJ (2008) Estimating the timing of long bone fractures: correlation between the postmortem interval, bone moisture content, and blunt force trauma fracture characteristics. J Forensic Sci 53:1028-1034

17. Ortner D (2008) Differential diagnosis of skeletal injuries. In: Kimmerle EH, Baraybar JP (eds) Skeletal Trauma. CRC Press, Florida, pp. 21-93

18. Galloway A, Zephro L (2005) Chapter 8: skeletal trauma analysis of the lower extremity. In: Rich J, Dean DE, Powers RH (eds) Forensic medicine of the lower extremity: human identification and trauma analysis of the thigh, leg, and foot. Humana Press, New Jersey, pp. 253-277

19. Gozna ER (1982) Biomechanics of long bone injuries. In: Gozna ER, Harrington IJ (eds) Biomechanics of musculoskeletal injuries. Williams and Wilkins, Baltimore, MD, pp. 1-24

20. Tencer AF (2006) Biomechanics of fixation and fractures. In: Rockwood CA, Green DP, Bucholz RW, Heckman JD (eds) Rockwood Green's fractures in adults, 6th edn. Lippincott-Raven, Philadelphia, pp. 3-42

21. Ebacher V, Tang C, McKay H et al (2007) Strain redistribution and cracking behavior of human bone during bending. Bone 40:12651275
22. Damkilde L (2000) Stress and stiffness analysis of beam-sections. Technical University of Denmark, http://homes.civil.aau. $\mathrm{dk} / \mathrm{lda} /$ Notes/CROSS.pdf. Accessed 10 June 2015

23. Rouvière H, Delmas A (1988) Anatomia humana. Masson, Barcelona

24. Kieser J (2013) Biomechanics of bone and bony trauma. In: Kieser J, Taylor M, Carr D (eds) Forensic biomechanics. Wiley-Blackwell, Oxford, pp. 35-70

25. Etxeberria F (2003) Patología Traumática. In: Isidro Llorens A, Malgosa Morera A (eds) Paleopathologia: la enfermedad no escrita. Masson, Barcelona

26. Sen S, Ando T, Kobayashi E et al (2014) Development of femoral bone fracture model simulating muscular contraction force by pneumatic rubber actuator. Eng Med Biol Soc:6872-6875

27. Pick TP (1885) Fractures and dislocations. Lea Brothers \& Company, Philadelphia

28. Porta DJ (2005) Chapter 9: biomechanics of impact injury. In: Rich J, Dean DE, Powers RH (eds) Forensic medicine of the lower extremity: human identification and trauma analysis of the thigh, leg, and foot. Humana Press, New Jersey, pp. 279-310

29. Kieser J, Taylor M, Carr D (2013) Forensic biomechanics. WileyBlackwell, Oxford

30. Botella MC, Aleman I, Jiménez SA (1999) Los huesos humanos, manipulación y alteraciones. Bellaterra, Barcelona

31. Moraitis K, Spiliopuolou C (2006) Identification and differential diagnosis of perimortem blunt force trauma in tubular long bones. Forensic Sci Med Pathol 2:221-229

32. Moraitis K, Eliopoulos C, Spiliopoulou C (2008) Fracture characteristics of perimortem trauma in skeletal material. Internet $\mathrm{J}$ Biol Anthropol 3:1-13 